\title{
Comparing the Nutritional Status of Organic and Conventional Oil-Bearing Rose (Rosa Damascena Mill.) Gardens in Lakes Region With Leaf and Flower Analyzes
}

\author{
İbrahim ERDAL* \\ Hilal MUNDUZ
}

Süleyman Demirel University, Agriculture Faculty, Soil Science and Plant Nutrition Department, Isparta, Turkey

*Sorumlu yazar e-mail (Corresponding author e-mail): ibrahimerdal@sdu.edu.tr

Geliș tarihi (Received) : 20.02.2017

Kabul tarihi (Accepted): 20.02.2017

DOI : 10.21657/topraksu.339828

\begin{abstract}
In this study, it was aimed to compare nutritional status of organic and conventional oil-bearing rose (Rosa damascena Mill) gardens in Lakes Region. For this, leaf and flower samples were collected from oil-bearing rose gardens in Lakes Region, Isparta. In these samples nitrogen, phosphorus, potassium, calcium, magnesium, iron, zinc, manganese, copper and boron analyses were made. When the leaf analysis results obtained from conventional and organic production areas were compared, it was seen that nutrient concentrations of the leaves from conventional gardens were higher generally. And these results were significant in terms of nitrogen, manganese, and zinc concentrations. Similarly, flower nutrient concentration of conventional gardens were higher for all examined nutrients and differences between organic and conventional gardens for nitrogen, potassium, calcium and iron concentrations were significant.
\end{abstract}

Key words: Conventional farming, organic farming, nutrient, oil-bearing rose

\section{Göller Yöresinde Organik ve Geleneksel Yetiștircilik Yapılan Yağ Gülü (Rosa damascena Mill.) Bahçelerinin Beslenme Durumlarının Yaprak ve Çiçek Analizleriyle Karșılaștırılması}

Öz

Bu çalıșmada Göller Yöresinde organik ve geleneksel yöntemlerle gül yetiștiriciliği yapılan bahçelerin beslenme durumlarının karșılaștırılması amaçlanmıștır. Bu nedenle Ispartada yağ gülü (Rosa damascena Mill) yetiștiriciliği yapılan alanlardan yaprak ve çiçek örnekleri toplanmıștır. Toplanan bu örneklerde azot, fosfor, potasyum, kalsiyum, magnezyum, demir, çinko, mangan, bakır ve bor analizleri yapıımıștır. Yaprak analiz sonuçlarına göre yapılan karșılaștırmada, genel olarak geleneksel yetiștiricilik yapılan bahçelerin besin elementi içeriklerinin daha yüksek olduğu görülmüș ve bu durum azot, mangan ve çinko için anlamlı bulunmuștur. Benzer șekilde, geleneksel yetiștircilik yapılan bahçelerden alınan çiçek besin elementi içeriklerinin de organik bahçelerden alınanlara göre daha fazla olduğu, ve bu durumun azot, potasyum, kalsiyum ve demir için önemli olduğu görülmüștür.

Anahtar Kelimeler: Geleneksel tarım, organik tarım, besin elementleri, yağ gülü 


\section{INTRODUCTION}

Despite there are some description on soil fertility, it is being used that soil fertility is "holding capacity of all physical, chemical and biological factors effecting high and quality yield in optimum levels and serving ability of water and nutrients on required time by plant". Fertile soils are rich in mineral elements needed by the plants. They contain sufficient amount of mineral nutrients, organic matter and microbial activity, the $\mathrm{pH}$ of the most of them are 6-7, they have good soil structure permitting good drainage and desired water holding capacity, and etc. Soils can lose their fertility properties with time depending on the use density. So, some additional precautions should be taken to protect their fertility. Nutrients in the soils can be lost with natural events such as leaching, erosion, fixation and denitrification processes or can decrease with the plant uptake. All plants require sufficient amount of available nutrients during their growth. And these nutrients should be supplied to meet plant demand. In a study conducted on barley, wheat and corn plants

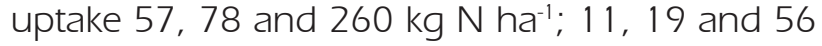
$\mathrm{kg} \mathrm{P} \mathrm{ha}^{-1} ; 40,47$ and $172 \mathrm{~kg} \mathrm{~K} \mathrm{ha}^{-1} ; 10,8$ and 31 kg Ca ha ${ }^{-1} ; 4,11$ and $31 \mathrm{~kg} \mathrm{Mg} \mathrm{ha}^{-1} ; 130,216$ and $529 \mathrm{~g} \mathrm{Zn} \mathrm{ha}^{-1}$ respectively (Mengel et al., 2001). In another study conducted by Erdal et al., (2006), it was found that tomato plant took $\mathrm{N}$ from the soil between 41.9- $196 \mathrm{~kg} \mathrm{ha}^{-1}$ depending on the irrigation program. El-Jendoubi et al., (2013) indicated that 3 years of peach trees giving about $60 \mathrm{~kg}$ fruits need 364, 59, 441, 575, 78, 5.2, 0.9, 1.0 and $1.1 \mathrm{~g}$ of $\mathrm{N}, \mathrm{P}, \mathrm{K}, \mathrm{Ca}, \mathrm{Mg}, \mathrm{Fe}, \mathrm{Mn}, \mathrm{Cu}$ and $\mathrm{Zn}$, respectively. Koseva (1978) reported that rose oil plant uptake $64 \mathrm{~kg} \mathrm{~N}, 8.7 \mathrm{~kg} \mathrm{P}$ and $36 \mathrm{~kg} \mathrm{~K}$ per hectare in a year. Also, Güçdemir (2006) noticed that oil-bearing rose plants need $40-160 \mathrm{~kg} \mathrm{~N}$, 9-36 kg P, 41-107 kg K per hectare depending on the conditions for a good yield. According to Baydar and Kazas (2013), 150 kg ha' diamonyum phosphate (18-46) in early spring and $200 \mathrm{~kg} \mathrm{ha}^{-1}$ ammonium sulphate in mid-season are needed to get $500 \mathrm{~kg}$ flower yield. Similarly, Singh and

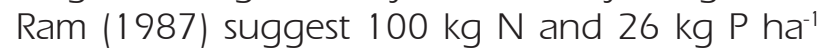
combination for high flower yield for oil rose plant.

As understood from the previous studies, plants require different amount nutrients. These requirements can be met from organic and inorganic sources in conventional farming. But, in, the organic farming, the use of inorganic materials for instance fertilizers are prohibited or depends on certain rules. So, in organic farming, providing plant's nutrient requirement with sufficient amount of all nutrients from organic fertilizers seems to be very difficult because of their low and slow release nutrient contents. So, sometimes growth and yield lose arise due to nutrient scarcity in organic farm soils.

Entz et al., (2001) conducted a research on crop yield and soil nutrient status on 14 organic farms. And they indicated that crop yields tended to be lower than those in conventional production, and that soil nutrient status was similar, and in some cases lower, than in conventional production. In a study presenting the results comparing soils managed organically for at least 15 years with soils under conventional management, on four arable farms in England, it was found that were no significant differences in total soil organic matter, total nitrogen or C: N ratio between the conventionally and organically managed soils. However, concentrations of extractable potassium and phosphorus were significantly lower in soils managed organically (Gosling and Shepherd 2005).

In this study it was aimed to compare the nutritional status of both organic and conventional oil-bearing rose gardens with leaf and flower analysis.

\section{Material and methods}

Leaf and flower samples from the 40 gardens (20 conventional and 20 organic) from Bașmakçı, Gönen, Kılıç, Yakaören, A. Beltarla, Senir, Andıçlı, Ayvalıpınar, Pazarköy and Sarıköy where intensively oil-bearing rose productions are made. Both orchards were selected depending on the records of Isparta Directorate of Provincial Food Agriculture and Livestock. Middle-aged leaves and fully-opened flower leaves were collected in May from the four sites of plants and put in the plastic bags. Samples were brought to the laboratory immediately and washed with top water and distilled water to remove surface residues. After washing, plants were dried at $65 \pm 5^{\circ} \mathrm{C}$ for 24 hours and grounded for nutrient analysis.

In order to determine $\mathrm{N}$ concentration, $0.5 \mathrm{~g}$ grounded samples were weighted in to the 250 $\mathrm{ml}$ macro-Kjeldahl tubes then $5 \mathrm{~g}$ of salt mixture 
and $10 \mathrm{ml}$ concentrated sulfuric acid $\left(\mathrm{H}_{2} \mathrm{SO}_{4}\right)$ was added. Then the tubes were placed in the digesting block at 350-400 ${ }^{\circ} \mathrm{C}$. After digesting, samples were distilled with sodium hydroxide (40\%, $\mathrm{NaOH})$. The ammonium $N$ was fixed in boric acid $\left(2 \%, \mathrm{H}_{3} \mathrm{BO}_{3}\right)$ and titrated with $0.1 \mathrm{~N}$ $\mathrm{H}_{2} \mathrm{SO}_{4}$. For determining nutrients (P, K, Ca, Mg, $\mathrm{Fe}, \mathrm{Zn}, \mathrm{Mn}, \mathrm{Fe}$ and B) apart from N, plant samples were wet digested using microwave digesting system and then filled up to $50 \mathrm{ml}$ with distilled water. Phosphorus and boron was determined calorimetrically using spectrophotometer, and the other nutrients were measured with atomic absorption spectrophotometer (Jones et al., 1991 ; Kacar and İnal 2008).

Comparisons of the leaf and flower nutrient concentrations of both orchards were made using COSTAT statistical software.

\section{Results and discussion}

\section{Comparing leaf nutrient concentrations}

Nutrient variations of conventional and organic farms have been seen in Table 1. Ass seen from there, minimum and maximum nutrient concentrations of conventional farms were 2.3$2.88 \%, \quad 0.85-1.70 \%, 0.80-1.35 \%, \quad 0.15-0.22 \%$, $0.20-0.34 \%, 51.2-59.3 \mathrm{mg} \mathrm{kg}{ }^{-1}, 95.1-157.4 \mathrm{mg}$ $\mathrm{kg}^{-1}, 16.5-35.6 \mathrm{mg} \mathrm{kg}^{-1}, 16.1-17.3 \mathrm{mg} \mathrm{kg}^{-1}$ and 41.6-55.1 $\mathrm{mg} \mathrm{kg}^{-1}$ for $\mathrm{N}, \mathrm{K}, \mathrm{Ca}, \mathrm{P}, \mathrm{Mg}, \mathrm{Fe}, \mathrm{Mn}$, $\mathrm{Zn}, \mathrm{Cu}$ and $\mathrm{B}$ respectively. These variations in organic farming were 2.29-2.56\%, 0.82-1.18\%, $1.0-1.51 \%, 0.13-0.22 \%, 0.20-0.33 \%, 52.1-67.3$ $\mathrm{mg} \mathrm{kg}{ }^{-1}$, 94.3-132.2 mg kg-1, 14.4-31.6 mg kg-1, 15.4-17.1 $\mathrm{mg} \mathrm{kg}^{-1}$ and $42.2-50.4 \mathrm{mg} \mathrm{kg}^{-1}$ for $\mathrm{N}$,
K, Ca, P, Mg, Fe, Mn, Zn, Cu and B respectively.

Comparison of nutrient concentrations of both conventional and organic oil-rose growing farms was given in Fig. 1 and in Fig. 2. As seen in Fig. 1, average values of conventional and organic farms for $\mathrm{N}, \mathrm{K}, \mathrm{Ca}, \mathrm{P}$ and $\mathrm{Mg}$ are 2.662.41\%, 1.13-0.99\%, 1.04-1.19\%, 0.19-0.18\% and $0.24-0.24 \%$ respectively. When compared both systems in terms of macro elements it was seen that there were not significant difference except for $\mathrm{N}$. But there was a significant variation for leaf $N$ concentrations and it was seen that $\mathrm{N}$ concentrations of conventional farms were significantly higher than organic farms.

Mean values of leaf micro nutrients obtained from conventional and organic farms were 56.3$59.1 \mathrm{mg} \mathrm{kg}^{-1}$ for Fe, $131.6-108.2 \mathrm{mg} \mathrm{kg}^{-1}$ for $\mathrm{Mn}$, 23.3-19.5 mg kg-1 for Zn, 16.7-16.5 mg kg-1 for $\mathrm{Cu}$ and $48.7-46.2 \mathrm{mg} \mathrm{kg}^{-1}$ for B. Looking at leaf micronutrient concentrations there were not

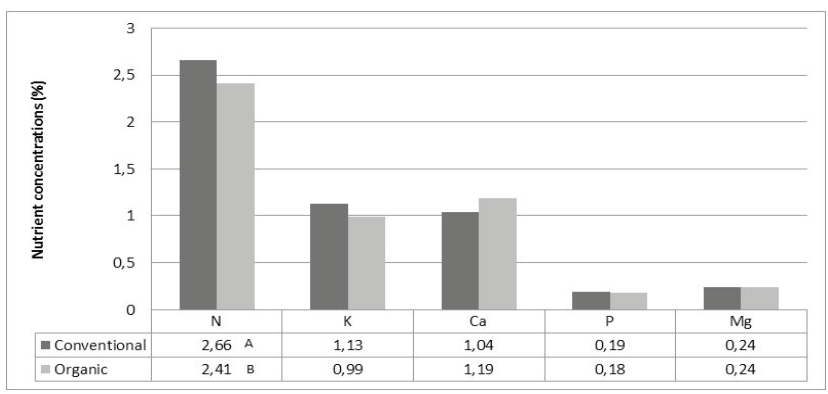

Figure 1. Leaf macro nutrient concentrations of conventional and organic rose farms

Șekil 1. Geleneksel ve organik gül bahçelerinin yaprak makro element konsantrasyonları

Table 1. Minimum, maximum and mean values of leaf nutrient concentrations of two farming systems

Çizelge 1. Iki üretim sisteminin yaprak besin elementi içeriklerinin en az, en fazla ve ortalama değerleri

\begin{tabular}{|c|c|c|c|c|c|c|}
\hline \multirow{2}{*}{ Nutrients } & Min. & Max. & Mean & Min. & Max. & Mean \\
\hline & \multicolumn{3}{|c|}{ Conventional farming } & \multicolumn{3}{|c|}{ Organic farming } \\
\hline N, \% & 2.30 & 2.88 & 2.66 & 2.29 & 2.56 & 2.41 \\
\hline K, \% & 0.85 & 1.70 & 1.13 & 0.82 & 1.18 & 0.99 \\
\hline Ca, \% & 0.80 & 1.35 & 1.04 & 1.00 & 1.51 & 1.19 \\
\hline$P, \%$ & 0.15 & 0.22 & 0.19 & 0.13 & 0.22 & 0.18 \\
\hline $\mathrm{Mg}, \%$ & 0.20 & 0.34 & 0.24 & 0.20 & 0.33 & 0.24 \\
\hline $\mathrm{Fe}, \mathrm{mg} \mathrm{kg}^{-1}$ & 51.20 & 59.30 & 56.3 & 52.10 & 67.30 & 59.10 \\
\hline $\mathrm{Mn}, \mathrm{mg} \mathrm{kg}{ }^{-1}$ & 95.10 & 157.40 & 131.6 & 94.30 & 132.2 & 108.20 \\
\hline Zn, mg kg-1 & 16.50 & 35.60 & 23.30 & 14.40 & 31.60 & 19.50 \\
\hline $\mathrm{Cu}, \mathrm{mg} \mathrm{kg}^{-1}$ & 16.10 & 17.30 & 16.70 & 15.40 & 17.10 & 16.50 \\
\hline $\mathrm{B}, \mathrm{mg} \mathrm{kg}^{-1}$ & 41.60 & 55.10 & 48.70 & 42.20 & 50.40 & 46.20 \\
\hline
\end{tabular}




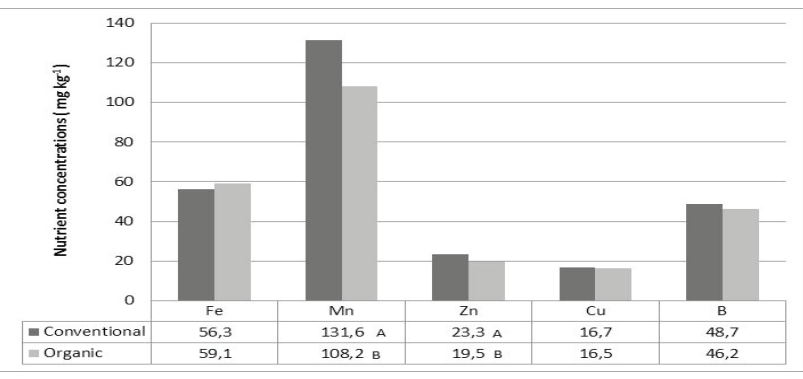

Figure 2. Leaf micro nutrient concentrations of conventional and organic rose farms

Șekil 2. Geleneksel ve organik gül bahçelerinin yaprak mikro element konsantrasyonları

significant differences between conventional and organic farms in terms of $\mathrm{Fe}, \mathrm{Zn}$ and $\mathrm{B}$. But, it was clearly seen that leaf $\mathrm{Mn}$ and $\mathrm{Zn}$ concentrations of conventional farms were significantly higher than organic farms.

\section{Comparing flower nutrient concentrations}

Flower nutrient variations of conventional and organic rose growing farms were $1.76-2.4 \%$ and $1.68-2.93 \%$ for $\mathrm{N}, 1.15-1.41 \%$ and $0.98-1.22 \%$ for $\mathrm{K}, 0.16-0.33 \%$ and $0.14-0.22 \%$ for $\mathrm{P}, 0.11$ $0.15 \%$ and $0.10-0.14 \%$ for Ca, 25.2-56.1 $\mathrm{mg} \mathrm{kg}^{-1}$ and $27.3-45.4 \mathrm{mg} \mathrm{kg}^{-1}$ for $\mathrm{Fe}$, 27.3-47.9 $\mathrm{mg} \mathrm{kg}^{-1}$ and $36.6-54.8 \mathrm{mg} \mathrm{kg}^{-1}$ for $\mathrm{Fe}, 19.5-28.5 \mathrm{mg} \mathrm{kg}^{-1}$ and $16.0-22.1 \mathrm{mg} \mathrm{kg}^{-1}$ For Zn, $14.3-18.3 \mathrm{mg} \mathrm{kg}^{-1}$ and $15.2-16.6$ for $\mathrm{Cu}$ and $16.4-22.2 \mathrm{mg} \mathrm{kg}^{-1}$ and $17.2-22.4 \mathrm{mg} \mathrm{kg}^{-1}$ for $\mathrm{B}$ respectively (Table 2 ).

Flower $\mathrm{N}, \mathrm{K}$ and $\mathrm{Ca}$ concentrations of conventional and organic farms were significantly different from the each other. Analysis results showed that $N, K$ and $C a$ concentrations of conventional farms were higher at the rate of $16 \%, 13 \%$ and $85 \%$ than organic farms. There were not a significant differences of leaf $\mathrm{P}$ and $\mathrm{Mg}$ concentrations between two farms (Fig. 3). While micronutrient concentrations of conventional farming systems were higher comparing to organic farming, there were not significant differences between two systems except for Fe (Fig. 4). Flower Fe concentration of conventional farms were about 28 percent higher than organic farms' flowers Fe concentration.

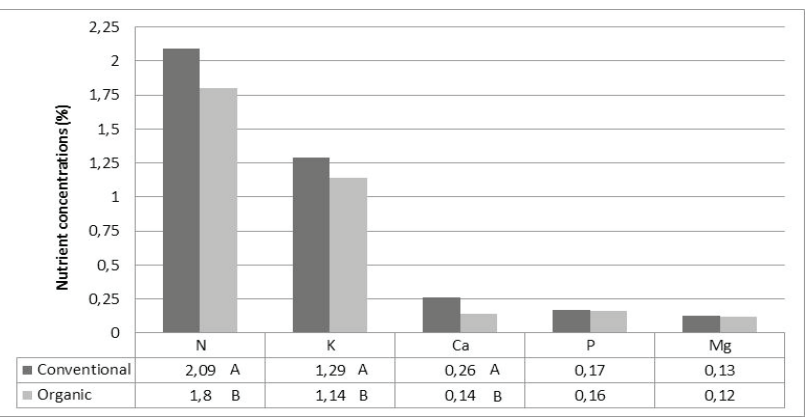

Figure 3. Comparing the flower macro nutrient concentrations of the oil-bearing rose gardens

Șekil 3. Yağ gülü bahçelerinin çiçek makro element konsantrasyonlarının karșılaștırılması

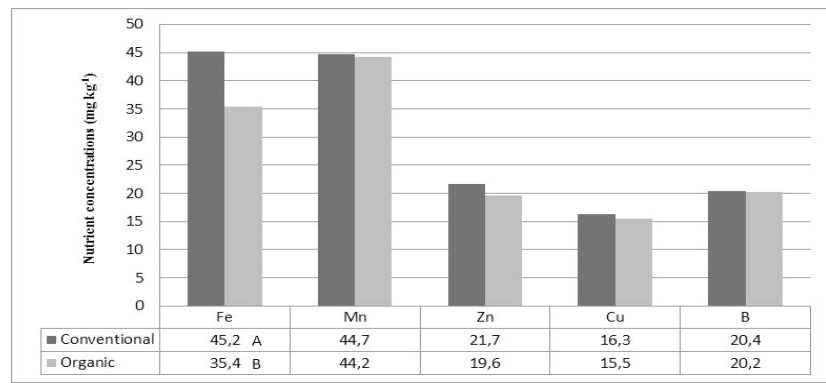

Figure 4. Comparing the flower micro nutrient concentrations of the oil-bearing rose gardens

Șekil 4. Yağ gülü bahçelerinin çiçek mikro element konsantrasyonlarinın karșılaștııılması

Table 2. Minimum, maximum and mean values of flower nutrient concentrations of two farming systems Çizelge 2. Iki üretim sisteminin çiçek besin elementi içeriklerinin en az, en fazla ve ortalama değerleri

\begin{tabular}{ccccccc}
\hline \multirow{2}{*}{ Nutrients } & Min. & Max. & Mean & Min. & Max. & Mean \\
\cline { 2 - 6 } N, \% & \multicolumn{3}{c}{ Conventional farming } & \multicolumn{3}{c}{ Organic farming } \\
K, \% & 1.76 & 2.40 & 2.09 & 1.68 & 1.93 & 1.80 \\
$\mathrm{Ca}, \%$ & 1.15 & 1.41 & 1.29 & 0.98 & 1.22 & 1.14 \\
$\mathrm{P}, \%$ & 0.16 & 0.33 & 0.26 & 0.11 & 0.16 & 0.16 \\
$\mathrm{Mg} \%$ & 0.16 & 0.18 & 0.17 & 0.14 & 0.22 & 0.16 \\
$\mathrm{Fe}, \mathrm{mg} \mathrm{kg}^{-1}$ & 0.11 & 0.15 & 0.13 & 0.10 & 0.14 & 0.12 \\
$\mathrm{Mn}, \mathrm{mg} \mathrm{kg}^{-1}$ & 25.20 & 56.10 & 45.20 & 27.30 & 45.40 & 35.40 \\
$\mathrm{Zn}, \mathrm{mg} \mathrm{kg}^{-1}$ & 27.30 & 47.90 & 44.70 & 36.60 & 54.80 & 44.20 \\
$\mathrm{Cu}, \mathrm{mg} \mathrm{kg}^{-1}$ & 19.50 & 28.50 & 21.70 & 16.00 & 22.10 & 19.60 \\
$\mathrm{~B}, \mathrm{mg} \mathrm{kg}^{-1}$ & 14.30 & 18.30 & 16.30 & 15.20 & 16.60 & 15.50 \\
\hline
\end{tabular}


From the analysis results of leaf and flower it can be seen that conventional rose gardens have higher nutrient concentrations generally. There were not significant differences in terms of some leaf and flower nutrient concentrations between both systems. However, three nutrients (N, Mn and $\mathrm{Zn}$ ) in leaves and four nutrients (N, K, Ca, $\mathrm{Fe}$ ) in flowers were significantly lower in organic farms comparing to the conventional farms. In a study conducted to compare the nutritional status and some quaility parameters of organic and conventional olive trees, it was indicated that there were not significant differences for examined parameters between both growing types (Zincirlioğlu, 2010).

As given previous works, nutrient concentrations of plant-available nutrients leading to higher plant nutrient uptake under conventional systems are higher (Ryan et al., 2004). Similarly, Entz et al., (2001) indicated that crop yields and nutritional status of organic farms tended to be lower than those in conventional production. These results are not un- expected because of the organic systems rules. As it is better known, organic systems are controlled by some rules and it is forbidden to use all fertilizers. So it is quite difficult to meet plants' all nutrient demand sufficiently with the fertilizers using in organic farming. In a study, it was reported that meeting all nutrient requirement, notably $\mathrm{N}$, of the plants (especially for perennials) from the organic sources is not possible (Pang and Letey, 2000). In another work depending on long period researches, it was reported that crop yields decreased by $20 \%$ in the organic farming systems (Mäder et al., 2002). Of course, there are many countries applying organic farming techniques without losing yield and quality by keeping soil fertility long time and it is possible with good management practices, particular crop types and growing conditions (Seufert et al., 2012). So, these techniques should be examined carefully and should be followed before applying organic farming. When looked at the previous study results carried out on rose gardens in the region, it can be seen that soils of the oil-bearing rose gardens already are poor in nutrient concentrations generally (Usta et al., 1994; Yalçın et al., 1994; Küçükyumuk and Erdal, 2008).

As conclusion, leaf and flower nutrient concentrations of organic oil rose orchards are lower when compared to the conventional orchards.
This may be due to poor quality of material given to the soil as fertilizers. If the necessary precautions are not taken to increase soil fertility, it may result in yield and quality loos with time.

\section{Acknowledgment}

We thank to SDU BAP for supporting this work.

\section{References}

Baydar H, Kazas S (2013). Yağ Gülü ve Isparta Gülcülüğü. Gülbirlik Yayınları 1

El-Jendoubi H, Abadía J, Abadía A (2013). Assessment of nutrient removal in bearing peach trees (Prunus Persica $\mathrm{L}$. Batsch) based on whole tree analysis. Plant and Soil, 369/12), 421-437

Entz M H, Guilford R, Gulden R (2001). Crop yield and soil nutrient status on 14 organic farms in the eastern portion of the northern Great Plains. Canadian Journal of Plant Science, $81(2), 351-354$

Erdal I, Ertek A, Șenyiğit U, Yılmaz H i (2006). Effects of different irrigation programs and nitrogen levels on nitrogen concentration, uptake and utilization in processing tomatoes (Lycopersicum Esculentum). Australian Journal of Experimental Agriculture, 46, 1653-1660

Gosling P, Shepherd M (2005). Long-term changes in soil fertility in organic arable farming systems in England, with particular reference to phosphorus and potassium. Agriculture, Ecosystems and Environment, 105(1), 425-432.

Güçdemir i H (2006). Türkiye Gübre ve Gübreleme Rehberi, 5. Baskı T.C. Tarım ve Köy ișleri Bakanlığı, Tarımsal Araștırma Genel Müdürlüğü, Ankara.

Jones Jr J.B, Wolf B, H A Mills (1991). Plant Analysis Handbook. A Practical Sampling, Preparation, Analysis, and Interpretation Guide. Micro-Macro Publishing, Inc, Athens Ga 891.

Kacar B, Inal A (2008). Plant Analysis. Nobel Pres, (1241),

Koseva D (1978). Effect of fertilizers on the utilization and removal of NPK by kazanlik rose. Rast. Nauki, 15 (8), 107-1 18.

Küçükyumuk Z, Erdal i (2008). Evaluation of nutritional status of rose gardens in Isparta district. 4. National Plant Nutrition Fertilizer and Congress. 8-10 Septembre. KonyaTurkey. 554-562.

Mäder P, Fliessbach A, Dubois D, Gunst L, Fried P, Niggli $U$ (2002). Soil fertility and biodiversity in organic farming. Science, 296 (5573), 1694-1697

Mengel K, Kirkby E A, Kosegarten H, Appel T (2001). Principles of Plant Nutrition (pp. 397-434). Springer Netherlands.

Pang X P, Letey J (2000). Organic farming challenge of timing nitrogen availability to crop nitrogen requirements. Soil Science Society of America Journal, 64(1), 247-253.

Ryan M H, Derrick J W, Dann P R (2004). Grain mineral concentrations and yield of wheat grown under organic and conventional management. Journal of the Science of Food and Agriculture, 84(3), 207-216 
Seufert V, Ramankutty N, Foley J A (2012). Comparing the yields of organic and conventional agriculture. Nature. 485 (7397): 229-232.

Singh D V, Ram M (1987). Effect of spacing, extent of pruning, growth hormone and nutrients on flower yield of essential oil bearing rose (Rosa damascene) in subtropical India. Acta Hortic. 208, 83-86.

Usta S, Yalçın R, Yüksel M, Topçuoğlu B (1994). Isparta Yöresinde Tarımı Yapılan Gül Bitkisinin Bazı Bitki Besin Maddesi İçerikleri Üzerinde Bir Araștırma. Ankara Üniversitesi Ziraat Fakültesi Yıllığı, 1 (4):183-190.
Yalçın R, Usta S, Yüksel M, Topçuoğlu B (1994). Gül Tarımı Yapılan Isparta Yöresinin Bazı Fiziksel ve Kimyasal Özellikleri. Ankara Üniversitesi Ziraat Fakültesi Yıllığı, 1(4): 191-198.

Zincirlioğlu N (2010). Organik ve Geleneksel Zeytin Yetiștiriciliğinde Bitki Beslenme Durumunun Meyve, Yaprak ve Zeytinyağında Önemli Kalite Ölçütleri Üzerindeki Etkilerinin Belirlenmesi. Ege Üniversitesi Fen Bilimleri Enstitüsü, Doktora Tezi, İzmir. Ege Üniversitesi Fen Bilimleri Enstitüsü. Doktora Tezi. 